\title{
Improving Learning Activities Using a Combination of Mind Mapping Model, Think Pair Share and Teams Game Tournament
}

\author{
Asniwati, Zain Ahmad Fauzi, Hidayatul Fikri \\ Faculty of Teacher Training and Education \\ Lambung Mangkurat University \\ Banjarmasin, Indonesia \\ zain.fauzi@ulm.ac.id
}

\begin{abstract}
The purpose of this study is to provide an overview of the implementation of classroom action regarding teacher's activity, student's activity, and student's learning outcomes with matters of the Joint Decision using a combination model of Mind Mapping, Think Pair Share, and Teams Game Tournament. This study used a qualitative research approach with a type of Classroom Action Research (CAR) carried out in four cycles. The Classroom Action Research subjects were 18 students of the fifth grade of SDN Pelambuan 7 . The data collected by using observation and tests. It was analyzed qualitatively and quantitatively. The results of this study indicate that teacher activity is improving and student activity as well as learning outcomes are increasing. Based on the results of this study, it can be concluded that using a combination model of Mind Mapping, Think Pair Share, and Teams Game Tournament models can improve teacher activity and increase student activity and learning outcomes.
\end{abstract}

Keywords-Student Learning Activities; Mind Mapping; Think Pair Share; Teams Game Tournament

\section{INTRODUCTION}

One of the subjects in Elementary School is Civics Education. This subject directs attention to morals expected to be realized in everyday life namely behavior that reflects faith and piety towards the God Almighty in a society. It consists of various groups, religion, humanitarian behavior that is just and fair, and behavior that supports national unity in diverse cultures and interests. As it is argued by [1], Civics Education is a subject used as a vehicle to develop and preserve noble values and morals rooted in Indonesian national culture. This moral and noble value is expected to realize in everyday life behavior of students as individuals, members of society, and creatures of the God Almighty. It is an effort to equip students with basic knowledge and abilities regarding relations among citizens, state, and preliminary education defending the country to become citizens who can be relied on by the nation and state.

Through the Civics Education subject, students are expected to be able to think critically, rationally, and be creative in responding to situations, participating intelligently and responsibly, and acting consciously in community, national and state activities. Ref. [1] stated that Civics Education aims to enable students to think critically, rationally, and creatively, be able to participate in all fields of activity actively and responsibly and can develop positively and democratically.

However, Civics Education is considered a difficult subject to understand. The vastness of Civics material makes it difficult for children to be invited to think critically and creatively, while elementary school children think they are still not formal because they are only in the concrete operational stage. What is considered logical, clear and can be learned for adults sometimes is something that is not reasonable and confusing for students.

The reality itself shows that not all students show satisfactory learning outcomes and has not been able to show an attitude of cooperation in daily interactions and various positive attitudes of citizens, such as help and obedience to worship. This is very far from Pancasila and Civics Education learning objectives. The objectives are thinking critically, rationally, and creatively in responding to the issue of citizenship, participating actively and responsibly, and acting intelligently in community activities, nation, and state. In addition, the other objectives are developing positively and democratically to shape themselves based on the characteristics of the Indonesian people in order to live together with other nations and interacting with other nations in the world directly or indirectly by utilizing information and communication technology.

Many students view Civics Education subject as a conceptual and theoretical subject. As a result, when students attending Pancasila and Civics Education learning, they feel enough to record and memorize concepts and theories that are taught by the teacher and do not do the given structured tasks seriously, or as a formality.

Based on the results of daily tests on Pancasila and Civics Education subjects in the 2016/2017 academic year at SDN Pelambuan 7 Banjarmasin, only 9 of 21 students or $42.86 \%$ achieved the Minimum Completion Criteria ( $\geq 72)$, while those who did not reach the Minimum Completion Criteria as many as 12 people or $57.14 \%$. Then, in $2015 / 2016$ out of 23 students only 13 students or $56.52 \%$ achieved the Minimum Completion Criteria $(\mathrm{KKM} \geq 72)$, while those who had not reached the 
Minimum Completion Criteria were 10 people or $43.48 \%$. The low student learning outcome indicates that the quality of school learning, especially in the VA class for Civics subject needs to be improved

From the results of the interview on October 20, 2017 with the VA homeroom teacher and the observation of the learning process, the obtained problem occurred in Pancasila and Civics education learning is especially in the Joint Decision material. The students could not master the learning material optimally. It is because the activities of students in the learning process are less active. They do not understand the theory of the lessons delivered by the teacher. The students are also less independent in learning activities. This is contrary to what is conveyed by [2] that "Students are expected to be actively involved in learning activities to think, interact, try, find new concepts or produce work".

In addition, students are very dependent on the teacher, so that learning is centered on the teacher and the learning outcomes obtained by students are only memorizing. Students do not know how important the subject matter is. There are still many old patterns in teaching that still survive today such as teaching using the lecturing method and not yet using a learning model that provides opportunities for students to be more active in learning as well as the causes of many students' values below the Minimum Completion Criteria.

Based on this condition, this problem needs to be addressed immediately. If this problem is left alone without prevention efforts, students are less interested in attending the lessons to be taught by the teacher, less active in the learning process, and easily get bored. It can make the learning becomes less effective and will affect the learning outcomes of the students themselves. Therefore, it is feared that the quality of education in schools will decrease in quality. From the problems, models or methods that can improve student learning outcomes are needed.

Based on the description above, a new strategy is needed to motivate students in learning the Joint Decisions in the field of Pancasila and Civics Education subject. To achieve good learning goals, it is important to actively involve students in the learning process by creating various kinds of student-centered learning models. One of them is by using a combination of Mind Mapping, Think Pair Share, and Teams Game Tournament models. The use of this combination is expected to motivate students to think critically and work together with their friends during the learning process. In addition, by using a combination of Mind Mapping, Think Pair Share, and Teams Game Tournament learning models, the learning becomes more fun, active, and creative.

During the learning process, Mind Mapping learning model is used for students initial knowledge. It is a model that uses students' brains as a center to obtain the studied information. This model guides students to map their thoughts on the material they are learning so that it is easy to understand and remember. This statement is in line with the opinion of reference [3] that the Mind Mapping learning model is very well used for students' initial knowledge or to find alternative answers.
Then, the Think Pair Share learning model, according to reference [4], is an effective way to vary the atmosphere of class discussion. With the procedure used in this model, that is to give students more time to think, respond, and help each other. It is expected that students are able to work together, need each other, and are interdependent on small groups cooperatively. This learning model is a model containing elements of the game and is challenging for students because there are academic competencies. Research studies on the combination of the Think Pair Share, Mind Mapping, and Teams Game Tournament models have been carried out by the other researchers and succeeded, as a study conducted by reference [5]. Her study reveals that using a Combined Mind Mapping Learning Models, Think Pair and Share (TPS) and Make a Match can improve student learning outcomes and a study by reference [6] explains that the application of the Teams Games Tournament model can improve student learning outcomes.

Based on the description of the background above, the researchers of this study try to solve the problem by conducting Classroom Action Research entitled: "Improving Learning Activities Using a Combination of Mind Mapping, Think Pair Share, and Teams Game Tournament." The purpose of this study is to provide an overview of the implementation of classroom actions regarding teacher's activity, student's activity and students' learning outcomes on the material of the Joint Decision using a combination of Mind Mapping, Think Pair Share, and Teams Game Tournament learning models.

\section{METHOD}

The study employed Classroom Action Research. It was carried out by following the research procedure based on the Principles of Kemmis and Taggart which have four stages. They are namely planning, implementation, observation, and reflection. The planning stage was in the form of planning the action to be carried out and preparing learning tools to be used. The implementation stage is the learning activities in the classroom as already arranged. The observation stage is the observation activity carried out when the second activity was carried out. Both of these stages cannot be separated because it will affect the final results of the study that is the reflection stage. It is the activity carried out to reiterate what has been done and to observe the weaknesses and lack of activities at the previous cycles and develop a plan for improvement at the next cycles.

This research was carried out at VA students of SDN Pelambuan 7 Banjarmasin, totalling 18 students. The study was conducted in the second semester of the 2017/2018 academic year. The object of this research is to increase the activities and student learning outcomes of Civics Education subject on Joint Decisions material using the combination of Mind Mapping learning model, Think Pair Share (TPS) and Team Games Tournaments.

The factors examined in this study include, (1) the activities of teachers, (2) student activities, and (3) student learning outcomes in Civics Education subject on Joint Decision material from student worksheets after using a combination of 
Mind Mapping learning model, Think Pair Share and Teams Game Tournaments.

The type of data presented in this study was qualitative data in the form of teacher activity data and student activities in the teaching and learning process activities and quantitative data in the form of student learning outcomes test scores carried out through written tests.

Indicators of success in this study are: (1) the activities of teachers in learning are categorized as successful if they reach a score on the observation sheet ranges between 24-28 with very good categories, (2) student activities in learning are categorized as successful when students have achieved scores with categories active and very active with a percentage between $61-100 \%$. Indicators of success in classical completeness reached $\geq 80 \%$ of all students, and (3) indicators of completeness of student learning outcome in this activity are if individual completeness reached $\geq 72$ (KKM score 72). Indicators of success in classical completeness reached $\geq 80 \%$ of all students achieved individual completeness scores of more than 72 (score> 72).

\section{RESUlTS AND DiscUSSION}

The research data shows that from the observation of learning the Joint Decision material using the combination of the Mind Mapping model, Think Pair Share and Teams Game Tournament from cycles 1 to 4, the teaching and learning have already implemented according to the learning plan. It is seen from the analysis of teacher activities, student activities and the completeness of learning outcomes that have achieved indicators of success. This can occur because of the learning carried out by the teacher. The increase in teacher activity scores can be seen in table 1 .

TABLE I. RECAPITULATION OF TEACHER ACTIVITIES

\begin{tabular}{|l|l|l|}
\hline \multirow{2}{*}{ Cycles } & \multicolumn{2}{|c|}{ Results } \\
\cline { 2 - 3 } & Score & Criteria \\
\hline 1 & 19 & Good \\
\hline 2 & 22 & Good \\
\hline 3 & 25 & Very Good \\
\hline 4 & 26 & Very Good \\
\hline
\end{tabular}

From Table 1, there is an increase in teacher activity scores in each cycle can be seen. This is because the teacher always makes efforts to improve the learning process that is being carried out by reflecting on every occurrence to achieve the appropriate criteria. In this study, the aspects of the teacher studied were seven aspects. From the 1 st cycle to the 4 th cycle, there are aspects that still get score 2 and score 3 for two cycles. This also has an impact on student activities and learning outcomes. However, in the 4th cycle only 2 aspects that have not reached a score of 4 . The increasing of teacher activity, student activity, and learning outcomes from cycle 1 to cycle 4 can be seen in Figure 1.

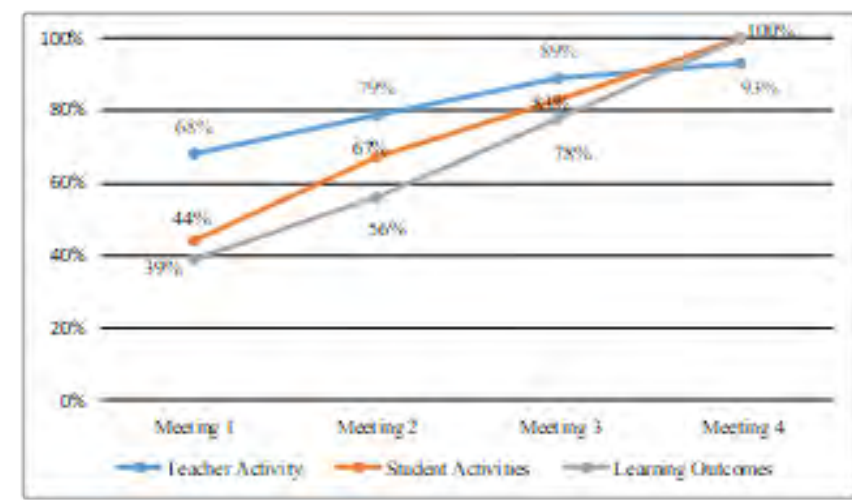

Fig. 1. Trend of Increasing Teacher Activity, Student Activities, and Learning Outcomes

Figure I shows that every cycle of teacher activity gets better, student activity increases, and student learning outcomes also increase. This proves that there is a relationship between the activities carried out by the teacher on student activities and the learning outcomes obtained.

From these data, it is seen that the more optimal the quality of activities carried out by the teacher, the better the quality improvement that occurs. In the teacher's activity at the beginning of cycle 1 , the teacher only got a score of 19 which when it was pressed to $68 \%$, and improved in cycles 4 with the score of 26 if it was suspended to $93 \%$. For student activities at cycle 1 is only $44 \%$ percent of students who achieved the criteria of active and very active, and increased at cycle 4 reaching $100 \%$ of students who achieved active and very active criteria. For the classical learning outcomes, the students who achieve learning completeness only 39\% increase at cycle 4 reaches $100 \%$.

Based on the results of this study, cycles 1 and 2 showed unsatisfactory results, and there were still many that needed to be improved. Meanwhile, the results of cycles 3 and 4 have increased and can reach the specified completeness indicators. This improvement occurs because of the efforts of the teacher in planning and implementing more maximal learning. Also, the reflection of the teacher after the learning process was maximized so that the future learning can run better. The teacher also always strives to improve the quality of learning in order to increase activity students in learning activities as a whole and can improve student learning outcomes. This is inseparable from the role of the teacher in conducting learning innovations. In accordance with the opinion stating that learning innovation is something that is important and must be owned by a teacher [4]. It is because learning will be more alive and meaningful.

The willingness of teachers to try to find, explore, and look for various breakthroughs, approaches, methods, and learning strategies is one of the supporting factors for the emergence of innovations. This learning innovation is by using innovative learning models such as cooperative learning supported by constructivist theory [7]. This learning arises from a difficult concept if they discuss with one another. The success of teachers in learning activities supports the success of students in learning. The process of collaboration between teachers and students in utilizing all potentials and resources is the potential 
that comes from within the students themselves, such as interests, talents, and basic abilities possessed including learning styles and potential that exist outside of students such as the environment, facilities and resources learning as an effort to achieve certain learning goals [8].

Learning is a combination that is composed of human, material, facilities, equipment, and procedures that influence the learning objectives. By using a combination of Mind Mapping, Think Pair Share, and Teams Game Tournament model, the teacher has encouraged, guided, and facilitated learning and involves important aspects of learning, namely teachers and students to improve learning outcomes and to achieve the objectives of the learning [9].

The Mind Mapping model is an important innovation to help produce meaningful learning in the classroom. Concept maps provide concrete visual assistance to help organize information before the information is learned [7].

Then, the Think Pair Share (TPS) model is a model developed by Frank Lyman and colleaguesth. TPS has procedures that explicitly give students time to think, answer, and help each other. Thus, students are expected to be able to work together, need each other, and interdependent on small groups cooperatively [4]. The main characteristic of this model is that the teacher gives students time to think, answer, and help each other by sharing from one group to another. One of the advantages of this model is that it provides time to think to improve the quality of student responses, make students more active in thinking about the concept of subjects, more understand of the concept of subject matter during the discussion [4].

In addition, the Teams Game Tournament model is one type or cooperative learning model that is easy to implement, involving the activities of all students without having status differences, involving the role of students as peer tutoring and contains elements of play and reinforcement [4]. This learning model is able to be a driver and reinforcement of students on the material delivered. Learning activities with games designed in cooperative learning TGT models allow students to learn more relaxed in addition to fostering responsibility, cooperation, healthy competition, and learning involvement.

From the above explanation and the opinions of the experts, the use of the combination of the Mind Mapping, Think Pair Share, and Teams Game Tournament can increase teacher activity and learning processes so that learning objectives are achieved optimally. This is also supported by previous research, that the application of the Mind Mapping model, Think Pair and Share (TPS) and Make a Match can increase teacher activity so that learning becomes effective [5][6][10].

The combination of Mind Mapping learning, Think Pair Share and Teams Game Tournaments is included in the cooperative learning model. Cooperative learning is the application of learning to small groups so that students can work together to maximize their own learning and maximize the learning of other group members [11]. It is a learning model using heterogeneous small grouping/team systems [3].

This shows a positive influence by applying the combination of Mind Mapping, Think Pair Share and Teams
Game Tournaments where this learning model places more emphasis on group collaboration in finding or solving problems (learning material) provided by the teacher. In this learning, students are required to be more active and creative in investigating a problem to foster their interest and motivation to learn together. To create active learning, one of them is the students learn from their experience. They also must learn to solve the problems they have [2]. Children also learn well and understand what is already known and the learning methods used are in accordance with their learning styles.

Mind Mapping is a creative way for each student to generate ideas, record what is learned, or plan new tasks [4]. Mind mapping helps students overcome difficulties, find out what they want to write, know what they want to write, and how to organize ideas.

The Think Pair Share learning model is a cooperative learning model that gives students time to think and respond and help each other. This model is able to change the assumption that recitation and discussion methods need to be held in the overall class group setting. Think Pair Share gives students time to think, respond, and help each other[4].

Meanwhile, the Teams Game Tournament model is able to be a driver and reinforcement of students on the material delivered. Learning activities with games designed in cooperative learning TGT models allow students to learn more relaxed in addition to fostering responsibility, cooperation, healthy competition, and learning involvement.

Teacher activity improves because improvements have been made to teacher readiness in providing learning as well as giving awards and motivation have been optimally given to students. With the appreciation and strong motivation of the teacher to take part in learning, student activities also increase. With the increase in student activity by itself the student learning outcomes will also increase.

Learning outcomes can be interpreted as the level of success of students in learning subject matter in schools which are expressed in scores obtained from the test results regarding a number of specific subject matter. To find out whether the learning outcomes achieved are in accordance with the desired goals can be known through evaluation [1].

According to the Gestalt theory, student learning outcomes are influenced by two things students themselves and their environment. First, students: in the sense of thinking ability or intellectual behavior, motivation, interests, and readiness of students, both physically and spiritually. Second, the environment: namely facilities and infrastructure, teacher competence, teacher creativity, learning resources, methods and support for the environment, family and environment [1].

Thus, in addition to factors in the students themselves, teachers also play an important role in making student learning outcomes more leverage. Motivation, the awarding, fun learning process and in accordance with the characteristics of children greatly influence student learning outcomes. One of the characteristics of children is the desire to form peer groups. 


\section{CONCLUSION}

By using a combination of Mind Mapping, Think Pair Share, and Teams Game Tournaments model, it can improve teacher activity, student learning activities and student learning outcomes in Civics Education Subject on Joint Decision Material in Class VA SDN Pelambuan 7 Banjarmasin.

\section{REFERENCES}

[1] A. Susanto, Teori Belajar Pembelajaran. Jakarta: Kencana Prenadameia Group, 2015.

[2] Uno, Belajar Dengan Pendekatan PAIKEM: Pembelajaran Aktif, Inovatif, Lingkungan, Kreatif, Efektif, Menarik. Jakarta: PT Bumi Aksara, 2014.

[3] A. Suriansyah, Aslamiah, Sulaiman, and Noorhafizah, Strategi Pembelajaran. Jakarta: PT Raja Grafindo Persada, 2014.

[4] A. Shoimin, Model Pembelajaran Inovatif Dalam Kurikulum 2013. Yogyakarta: Ar-Ruzz Media, 2014.
[5] N. Helmatunnisa, "Meningkatkan Hasil Belajar PKn Tentang Globalisasi Melalui Kombinasi Model Pembelajaran Mind Mapping, Think Pair And Share Dan Meke A Match Pada Kelas IVB SDN Semangat Dalam 1 Kab. Barito Kuala."

[6] Anshori, "Penggunaan Teams Games Tournament Di Kelas IV MI AlIslamiyah Kecamatan Beji Kota Depok."

[7] Trianto, Mendesain Model Pembelajaran Inovatif, Progresif, dan Kontekstual: Konsep, Landasan dan Impelementasi Pada Kurikulum 2013 (Kurikulum Tematik Integratif (KTI). Jakarta: Prenadamedia Group, 2014.

[8] W. Sanjaya, Strategi Pembelajaran: Orientasi Standar Proses Pendidikan. Jakarta: Kencana Prenadademia, 2013.

[9] O. Hamalik, Kurikulum dan Pembelajaran. Jakarta: Bumi Aksara, 2014.

[10] A. Aisyah, "Pengguna Model Cooperative Learning Tipe Think Pair Share Untuk Meningkatkan Hasil Belajar PKn Pada Siswa Kelas IV SD Muhammadiyah Palu," J. Kreat. Tadulako Online, vol. 4, no. 4.

[11] Warsono and Hariyanto, Pembelajaran aktif. Bandung: Remaja Rosdakarya, 2013. 